\title{
LA CARACTERIZACIÓN DE LOS PERSONAJES A TRAVÉS DE LAS IMÁGENES DE CINE EN LA OBRA DE MANUEL RIVAS
}

\section{CHARACTERIZATION THROUGH FILM IMAGES IN THE WORK OF MANUEL RIVAS}

\section{Salvador CASTRO OTERO}

I. E. S. de Rodeira, Cangas do Morrazo (Pontevedra)

Resumen: El texto defiende la influencia del cine en los narradores literarios contemporáneos, de modo especial en Manuel Rivas. Intenta mostrar como este creador se vale de elementos del cine - especialmente actores y personajes - para caracterizar a personas o criaturas de su propia ficción. Al mismo tiempo, la interpretación de las películas o de los héroes de las mismas también constituyen un elemento caracterizador.

Palabras clave: Manuel Rivas; literatura comparada, cine y literatura, periodismo, caracterización de los personajes

Abstract: This paper defends the influence of cinema on contemporary literary narrators, especially in Manuel Rivas. It tries to show how this creator uses elements of the cinema - especially actors and characters - to characterize people or creatures of his own fiction. At the same time, the interpretation of the films or the heroes also constitute a characterizing element.

Keywords: Manuel Rivas; comparative literature; cinema and literatura, journalism, characterization. 
1 homo sapiens ha tenido siempre una imperiosa necesidad de contar historias, de acoger relatos: «Muchas cosas han cambiado para el ser humano pero una necesidad se mantiene, la de inventar historias para alimentar el fuego y prolongar las mil y una noches» (Martín de Blas, 1999) ${ }^{1}$. Este apetito ha sido colmado a través de los tiempos con narraciones orales, con los relatos escritos, con las distintas formas del audiovisual contemporáneo y, con seguridad, formará parte de lo esencial de nuestra especie hasta el infinito y más allá.

Cuando a finales del siglo XIX los hermanos Lumière realizan la primera exhibición con su cinematógrafo no podían sospechar la enorme repercusión de su invento y, sin embargo, este aparato mágico capaz de mostrar en imágenes el movimiento cautivó inmediatamente al público, por lo que pronto proliferaron las grabaciones y las proyecciones se extendieron con rapidez. Aunque los propios inventores ya habían rodado una peripecia de ficción - El regador regado-, podemos considerar a Méliès como el primero en transcender la función documental del cine ${ }^{2}$. Este realizador llevará a las pantallas sus espectáculos de magia y sus ficciones. Cuando ya en 1899 adapta el cuento de Cenicienta seguramente no podía imaginar que había abierto una de las puertas más fecundas en las relaciones del cine con las demás artes. Desde ese momento el cine se nutrirá constantemente de las ficciones literarias, se apropiará de sus argumentos y de sus palabras y de sus técnicas. Este intercambio llega a ser asimilado de tal forma que recursos procedentes de la literatura acabarán por considerarse como propios del cine: es el caso de la narración paralela cuya invención se atribuye a David W. Griffith, pese a que el mismo director norteamericano reconoció que la había tomado de Dickens ${ }^{3}$. El caso es que, aunque tardará en ser reconocido como arte, el cine se convertirá en la forma de narración más popular a lo largo del siglo Xx. De hecho, la gran mayoría de los ciudadanos, al menos en los países más ricos, han contemplado más películas que leído libros; son más espectadores que lectores. Además la presencia de la televisión en los hogares transforma en diaria esta recepción audiovisual. En su discurso de ingreso en la RAE, Luís Goytisolo señalaba:

La aparición de la TV y, sobre todo, la generalización del fenómeno televisivo supone un nuevo y más decisivo factor condicionante en el desarrollo de la narrativa, no ya desde el punto de vista formal y técnico, sino también sociológico. Afecta de un modo directo a la lectura - justamente por lo que tiene de cotidiano y doméstico- e indirectamente a la propia escritura, en la medida en que todo nuevo escritor ha sido y es, además de lector, telespectador más o menos asiduo. El fenómeno televisivo —expresión con la que designo la estrecha dependencia creada entre programación televisiva y público- no supone en efecto una mera elección alternativa, como la que puede existir entre leer e ir al cine. Más que una opción es una invasión: invade pura y simplemente, a domicilio, la vida cotidiana, y antes que interpretar la realidad circundante, la sustituye, se constituye en realidad y entra a formar parte del reparto del horario del día — un tiempo como

\footnotetext{
${ }^{1}$ La cita está extraída del documental Galicia, arpa de niebla, incluida en la serie Esta es mi tierra emitida por Televisión Española. El director del episodio fue Juan M. Martín de Blas y el guion fue redactado por Adolfo Dufour, Juan M. Martín de Blas y el propio Manuel Rivas, que actúa además como narrador.

${ }^{2}$ En realidad toda película es un documental, de modo que El espíritu de la colmena, pongamos por ejemplo, es al mismo tiempo una película de ficción y un documental sobre cómo se rodó esa obra.

${ }^{3}$ Por otro lado la narración paralela ya estaba presente en El Quijote.
} 


\section{La caracterización de los personajes a través de las imágenes de cine en la obra de M. Rivas}

el destinado a comer o a dormir - en la vida de un número cada vez mayor de individuos. El fondo del problema no reside - como tanto se nos repite- en que, a causa de esta invasión, se vaya menos al cine o se lea menos; el verdadero núcleo del problema estriba en que el fenómeno televisivo tiende a excluir a la vez una y otra actividad en beneficio de una nueva forma de privacidad que, de un modo natural, tiende a establecerse directamente entre el televisor y el telespectador (Goytisolo, 1995: 22-23).

Por todo esto, y de igual modo que denominamos a la generación actual —-formada por los nacidos cuando la tecnología digital ya estaba muy desarrollada y formaba parte de la vida cotidianacomo homo sapiens digitalis; creemos que las generaciones, cuya forma mayoritaria de saciar su sed de historias se encuentra en el cine, bien podrían ser denominadas homo fílmicus.

Ya que la presencia del audiovisual en la vida y formación de estas promociones es tan importante, no puede extrañarnos que las formas de narrar del séptimo arte hayan dejado huellas en la forma de contar de los literatos. El propio Goytisolo sostiene que no es posible una actitud neutral ante este hecho y que los autores optan o por aproximarse al nuevo género o por apartarse de modo consciente, lo que no deja de ser un influjo:

Centrándonos ya en nuestro asunto, yo diría que la narrativa española contemporánea — sin distinguirse demasiado en este sentido de la narrativa de otros países europeos- ha reaccionado ante el relato cinematográfico fundamentalmente de dos maneras. La primera de ellas consistiría en un movimiento de aproximación al nuevo género tendente a asimilar sus recursos del modo más completo posible a fin de poder competir con él ofreciendo al lector un producto análogo, por más que expresado en palabras.

[...] De ahí que, frente a esa tendencia, desarrollada de forma paralela y simultánea, se nos ofrezca la tendencia opuesta, que busca, antes que aproximarse a la imagen, apartarse de ella, crearse un propio ámbito irreductible (1995: 25-26).

Entre las influencias en la forma de escribir, procedentes del cine, el académico incluye la narración en secuencias y no en capítulos, el carácter enunciativo y coloquial de los diálogos, la irrupción de una narrativa visual y no verbal y el predominio del relato en tercera persona.

Patricia Antón (2007), por su parte, añade algunas otras características a las ya mencionadas: el carácter visual de las descripciones, reforzado por la ocularización —la narración de lo que unos ojos ven, a veces, imitando el movimiento de una cámara-; la aparición de una imagen dentro de otra imagen - por ejemplo, dentro de un espejo-; el uso de los ruidos a modo de una banda sonora, como un fondo ambiental; el uso simbólico de la luz y finalmente la intertextualidad. Otros autores como Teresa García-Abad (2005: 109) señalan la influencia del montaje cinematográfico en los textos literarios. De modo que, aquí y allá, son numerosos los investigadores que detectan la influencia del séptimo arte, aunque quizás fuese preciso un estudio ordenado y sistemático de los mismos.

En nuestra opinión, las huellas del cine en la literatura son de cuatro tipos: estructurales -la división en secuencias, el montaje, la ocularización y la auriculización-, visuales —el empleo de una descripción visual que imita los distintos tipos de plano o los movimientos de cámara, la presencia de la imagen dentro de la imagen y el uso simbólico de la luz-, auditivas — los diálogos enunciativos y el uso de la música y los ruidos como banda sonora- e intertextuales. 
Manuel Rivas es uno de los escritores en lengua gallega ${ }^{4}$ más reconocidos de la actualidad. $\mathrm{Su}$ obra ha sido la más traducida de un autor en esta lengua en toda la historia ${ }^{5}$; ha recibido numerosos premios $^{6}$; ha sido objeto de estudio en algunas de las más prestigiosas universidades del mundo ${ }^{7}$ y tiene un amplio reconocimiento de público y crítica $^{8}$. Su relación con el cine no se debe únicamente a formar parte de las generaciones del homo filmicus, sino que ha sido el guionista de los documentales Galicia, arpa de niebla y E punto final y del largometraje Todo es silencio, e incluso ha dirigido el cortometraje titulado Mayday, Mayday, sobre la catástrofe del Prestige.

Pero, dejando a un lado su labor en el cine, nos interesa destacar aquí las abundantísimas mencionesal séptimo arte en su literatura. En sus obras nos encontramos con más de ciento cincuenta películas diferentes, más de setenta y cinco directores, más de cincuenta actores y más de cincuenta personajes; pero también con oficios menos glamurosos como directores de fotografía, maquilladoras, extras, meritorios, acomodadores, pertiguistas, etc.; además de alusiones a las salas de cine, a las técnicas, a los géneros e incluso a la tecnología de este arte.

Estos datos podrían constituir una simple anécdota, una demostración de erudición, pero, si analizamos con detenimiento las menciones al cine en la obra de este creador, observamos que por momentos alcanzan una gran intensidad. El séptimo arte se convierte en una metáfora para expresar la belleza del mundo, la intensidad de la vida, cuando esta parece elevarse por encima de lo posible:

E pasaban os cabalos en panorámica de lusco fusco, coma se quixesen ofrecerlle unha película inesquecible (Episodios galegos. Tempos de esperpento, p. 63$)^{9}$.

E aló van os pasaxeiros gozando na xanela deste filme de culto chamado Galicia (Galicia, Galicia, p. 252).

Tal vez uno de los textos más emocionantes de Rivas sea el titulado «O galego e a Santa Compaña», incluido en el volumen Unha espía no reino de Galicia. Narra la historia de un alma en pena que busca un lugar donde ser recibido. Visita a sus antiguos familiares que no pueden atenderlo porque están contemplando en la televisión una película de Drácula ${ }^{10}$, justo en el instante en que este es nombrado presidente de Transilvania. Pero cuando el ser de ultratumba es por fin acogido, cuando se encuentra con alguien que comparte sus claves y siente una emoción que parece devolverlo a la

\footnotetext{
${ }^{4}$ Hemos optado por transcribir las citas en el idioma original de la obra para conservar así el ritmo y los matices del autor. ${ }^{5}$ Está traducido a más de veinte lenguas que incluyen las más extendidas: inglés, francés, alemán, italiano o ruso, pero también a otras menos habladas como el tetún, el húngaro, el hebreo o el danés (Castro Otero y otros, 2011: 11).

${ }^{6}$ Entre otros el Premio Torrente Ballester de Narrativa, el Premio Nacional de Narrativa, tres Premios de la Crítica Española y dos de la Crítica Gallega.

${ }^{7}$ El Centre de Recherches Interdisciplinaires sur les Mondes Ibériques Contemporains organizó en marzo de 2010 unas jornadas sobre Manuel Rivas y Suso de Toro tituladas Manuel Rivas et Suso de Toro: deux voix de la littérature galicienne contemporaine.

${ }^{8}$ En palabras de Günter Grass —Premio Nobel de Literatura 1999—, «he aprendido más de la guerra civil española leyendo El lápiz del carpintero de Manuel Rivas, que en todos los libros de historia» (cit. en https://www.megustaleer.com/libros/ellpiz-del-carpintero/MES-066255; última consulta, 1-7-2018).

${ }^{9}$ Hemos decidido, en las obras del autor estudiado, consignar el nombre completo de la obra porque podría facilitar el recuerdo del contexto a quien las hubiese leído. Sin necesidad de buscar en la bibliografía la fecha y, a través de ella, el título de la misma.

${ }^{10}$ Repárese en la ironía que supone que el familiar está a disfrutar de una película de terror, de un ser de ultratumba y no atiende a sus propios seres del más allá.
} 
vida, cuando siente de nuevo los latidos del reloj parado del corazón, no puede expresar esa emoción más que a través de una imagen de cine, hasta el punto de que el humo se transubstancia en película, provocándole una emoción sublime y revitalizadora:

Por iso, cando a ánima en pena asoma pola fiestra e encontra un galego de seu mirando a lendaria película do lume de ameneiro na lareira, sente de novo latexos no reloxo do corazón e peta cos cotenos unha pandeirada no vidro. O galego O`Fetén ábrelle a porta, mándao pasar e ofrécelle, claro, algo de cea (Unha espía no reino de Galicia, p. 52).

Toda vez que el ingente material, antes citado, es imposible de abarcar en un trabajo de estas dimensiones, en este artículo nos limitaremos a analizar un aspecto concreto de las relaciones intertextuales: aquel que afecta a la caracterización de los personajes.

Somos conscientes de que un autor como Manuel Rivas sobrevuela las fronteras de los géneros literarios con libertad. De modo que resulta inapropiado establecer una barrera rígida entre a producción literaria e la periodística ${ }^{11}$. El propio autor nos lo advierte:

Digo escritor y no periodista a sabiendas. Para mí siempre fueron el mismo oficio. El periodista es un escritor. Trabaja con palabras. Busca comunicar una historia y lo hace con una voluntad de estilo. La realidad y parte de mis colegas se empeñan en desmentirme. Pero sigo creyendo lo mismo (El periodismo es un cuento, p. 19).

$\mathrm{Al}$ escritor que es periodista se le supone una tumultuosa querella interna, como si trabajara con partes distintas del cerebro para escribir un reportaje o un cuento. Se supone también con frecuencia que la disposición mental es distinta cuando uno afronta una novela, una obra de arte, o un relato periodístico, que vendría a ser una artesanía menor. Me han preguntado muchas veces cómo llevo esa esquizofrenia. No tengo conciencia de esa fractura y por lo tanto me merezco el desprecio de algunos críticos y escritores puros que me sitúan en el purgatorio de la literatura. Vivo cualquier suceso con la perplejidad de un extraterrestre. Creo que el hecho más irrelevante puede esconder una piedra de toque, el comienzo de un asunto interesante. Prefiero seguir a un campesino en burro que a la comitiva motorizada de Manuel Fraga, pero si es Fraga quien va en burro procuraré estar a la altura de las circunstancias (El periodismo es un cuento, pp. 22-23).

No obstante, el receptor no aborda igual un texto periodístico, por imaginativo que este sea, que un texto literario por más que esté basado en hechos reales y por más mimético que este sea. El propio Rivas matiza sus palabras anteriores al expresar:

¿Y qué hay de la diferencia entre ficción y realidad? Esto no es un tratado, así que no me voy a poner pelma. El periodismo tiene unas exigencias, a las que no está sometida la literatura. Los protagonistas de la noticia deben figurar en el registro civil. En un relato literario, no. Pero ¿son por ello menos reales Don Quijote o Emma Bovary? (El periodismo es un cuento, p. 23).

En nuestro trabajo, nos referiremos tanto a la caracterización de las personas, aquellas que aparecen en el registro civil, como de los personajes, que no aparecen ${ }^{12}$ de su obra periodística y literaria de Rivas.

\footnotetext{
${ }^{11}$ Sería muy difícil abarcar aquí toda amplísima obra periodística de Rivas, por eso nos vamos a analizar aquí, además de su obra literaria, sus artículos publicados en formato libro - Galicia, o bonsái Atlántico, Unha espía no reino de Galicia, Galicia, Galicia, El periodismo es un cuento, Episodios galegos. Tempos de esperpento, A corpo aberto, Toxos e Flores, Galicia Neghra y No mellor país do mundo-.

${ }^{12}$ En ocasiones Rivas emplea este recurso también para describir objetos, así por ejemplo a mesa de Ramón Piñeiro era «unha variante galega e camuflada de HAL 9000», y las estatuas promovidas por Francisco Vázquez en su época de alcalde de A Coruña se parecían, según nuestro autor, a actrices y modelos famosas: «Ou, xa que foi idea do noso embaixador
} 
Patricia Antón (2007: 263) señalaba que «la segunda variante de la intertextualidad fílmica implica la identificación del personaje con la ficción cinematográfica». Estas alusiones pueden referirse tanto al aspecto físico — prosopografía - como al psicológico-moral —etopeya- ${ }^{13}$. En realidad, como veremos, esa distinción es un tanto arbitraria pues, muchas veces, la vestimenta o el aspecto más que mostrar un aspecto exterior manifiesta un modo de ser o de comportarse y determinadas actitudes morales nos invitan a una determinada percepción física. Así, por ejemplo, cuando Manuel Rivas escribe: «Comenzó el curso escolar. A Gervas, que tiene un cierto parecido con Woody Allen, ya se le ha puesto cara de Arnold Schwarzenegger. Mi amigo es profesor. Maestro, dice él» (El periodismo es un cuento, p. 144).

Aunque el autor describe una metamorfosis física, el aspecto de Woddy Allen se transforma en cara de Schwarzenegger, en realidad, es su carácter el que cambia.

Comencemos pues, con estas prevenciones, con las prosopografías:

En numerosas ocasiones, el autor refleja el aspecto general de la persona descrita comparándolo con un actor/actriz o personaje de la ficción:

Bebió más de la cuenta y ligó con una pensionista encantadora que se parecía a Lauren Bacall ( $E l$ periodismo es un cuento, p. 345).

Por suposto que é de carne e óso, pero se puidésemos reconstruílo figuradamente, como quen novela un replicante de Blade Runner de Ridley Scott, Mass Fraga sería unha mestura soldado de chumbo de linotipia, telefonía, emisor de ondas, cátodos televisivos e un chimpín que abre pola pista forestal en Internet (Galicia, Galicia, p. 274).

Un ejemplo curioso de identificación lo encontramos en el artículo titulado «Martin Sheen e Méndez Ferrín», incluido en el volumen Episodios galegos. Tempos de esperpento. Rivas relata una anécdota ocurrida en Gondomar donde el autor creyó encontrar aun sosias del protagonista de Apocalyse Now:

E a medida que pasaba o tempo, e o Miño, coma quen di, nos levaba ao corazón da escuridade, mais se asemellaba o ghicho ao grandísimo actor de Apocalypse Now» (Episodios galegos. Tempos de esperpento, p. 113).

Claro que el hombre que se parecía a Martin Sheen no era otro que Martin Sheen ${ }^{14}$, confirmando que lo suele parecer a algo, acaba por ser ese algo.

En otras ocasiones el personaje se muestra a partir de suatuendo. Las referencias a la totalidad o a parte de la indumentaria pueden señalarsimplemente una caracterización tópica:

Mientras el primer gallego que aparece en los filmes españoles es Xan das Bolas vestido de sereno o afilador (Galicia, el bonsái atlántico, p. 56).

\footnotetext{
romano, polo menos que se parecera a Ana Magnani en Mamma Roma. Mais xa estou a ver no Parrote a unha Virxe do Carme tipo Carla Bruni e con gafas de sol» (Episodios galegos. Tempos de esperpento, p. 199).

13 A veces la comparación no se establece a través del aspecto físico o de la personalidad, sino en el nombre: «Era propiedade dun home a quen chaman O' Garicupa porque un día dixo que se encontraba só ante o perigo xogando unha partida de dominó» (Unha espía no reino de Galicia, p. 110).

${ }^{14} \mathrm{El}$ padre del actor era originario de Salceda de Caselas, de ahí las visitas a Galicia de este famoso intérprete.
} 


\section{La caracterización de los personajes a través de las imágenes de cine en la obra de M. Rivas}

En ocasiones adquieren un sentido paródico o humorístico:

Portomeñe ${ }^{15}$ gastaba para a ocasión un traxe caqui de explorador, ó estilo de Robert Redford en Memorias de África, e mostrábase sumamente xovial no seu trato cos periodistas (Galicia, Galicia, p. 84).

Incluso en alguna ocasión el traje puede denotar un sentido transcendente:

Baixo a chuvia de pedras, vexo a Luís Pita sorrir coa súa gabardina existencialista ${ }^{16}$ que xa foi de Bogart e de Camus (Galicia, Galicia, p. 287).

A veces, las citas hacen referencia, no a la totalidad sino a partes del cuerpo humano. Los ojos son, sin duda, el órgano que Rivas menciona con más originalidad e intensidad. Además de las simples menciones del parecido:

Un dos principais órganos de expresión dos cans son os ollos, e a súa mirada, en determinadas circunstancias, lémbrame moito a de Jacques Tati (A corpo aberto, p. 311).

Imos facer un experimento. Se lle tapamos o lado esquerdo da cara (para nós o seu lado dereito), o ollo e a boca rideira, quédanos un ollo, ollo dereito dela, o noso ollo esquerdo, que expresa claramente o pánico. É o ollo que nos recorda un fotograma de Psicose o filme de Alfred Hitchcock, rodado precisamente nesta época, unha historia que pode ter bastante que ve con toda estoutra película que estou eu a contar (Muller no baño, p. 30).

Rivas realiza una verdadera exhibición de su habilidad para describir los personajes a través de imágenes cinematográficas, al apropiarse de la fuerza de los ojos de Bela Lugosi, en su papel de Drácula. Son demoníacos, malvados; lo que le permite criticar a famosos políticos o caracterizar a personajesrepresores y brutales. 720).

Xúroche que tiña a mesma luz de ollos que aquel do cinema, o Bela Lugosi (Os libros arden mal, p.

Exercía unha atracción temerosa, sobre todo en partidarios e subalternos, similar ao efecto «luz de ollos» de Bela Lugosi en Drácula ${ }^{17}$ (1931) (A corpo aberto, p. 207).

Permítasenos detenernos en un uso de los ojos de Lugosi, que si bien no es caracterizador en sentido estricto, constituye, por su originalidad, uno de los logros del autor. Rivas, como si homenajease a El moderno Sherlock Holmes (Sherlock Holmes Jr, Buster Keaton, 1924) o a La rosa púrpura del Cairo (The Purple Rose of Cairo, Woody Allen, 1985), consigue romper la barrera entre la pantalla y los espectadores, tender un puente entre esos dos mundos y provocar que un acto realizado

\footnotetext{
${ }^{15}$ Conviene señalar que, si bien Vázquez Portomeñe era un destacado y conocido miembro del gobierno gallego, el texto que incluye la cita es una ficción política. Un relato imaginario de un entonces impensable viaje de Manuel Fraga a la Cuba de Fidel Castro. De modo que, de nuevo, Rivas se mueve en esa delicada frontera entre lo real periodístico y lo ficticio literario.

${ }^{16}$ Fijémonos una vez más en lo difícil que resulta incluir bajo una única etiqueta un ejemplo, es evidente que «gabardina existencialista» contiene una carga psicológica y filosófica mocho mayor que la mera coincidencia en el uso de una prenda. ${ }^{17}$ Aquí se refiere al expresidente del gobierno español, José María Aznar.
} 
en la ficción cinematográfica deje huella física en el mundo real ${ }^{18}$ : la mirada del actor produce unos agujeros en la pantalla:

Os ollos coa luz de ollos do que facía de Drácula, que aínda queimou a pantalla do cine Hércules, dous buracos deixou alí, como queimaduras de cigarro (p. 720).

Rivas también se vale de rasgos como la voz y la risa o la sonrisa:

De feito, Piñeiro tiña unha voz cuspidiña á de Douglas Rain, o actor que facía de HAL (Episodios galegos. Tempos de esperpento, p. 223).

Pero foi e saíu unha sintonía de Star Wars, despois unha gargallada tipo Jack Nicholson e unha lacónica mensaxe en inglés, seguida dun nítido "¡Manda carallo!" en galego (Muller no baño, p. 82).

Reflectía na gran cristaleira o saúdo festeiro de Leica nun dos seus sorrisos «Mastroianni» (Os libros arden mal, p. 532).

Otros rasgos de la cara como el bigote, el hoyuelo o el afeitado también son trazos de los que se sirve nuestro autor para describirnos a sus criaturas:

Era tamén de moi bo ver. As cousas como son. Lanzal, moi galán co seu bigote ao estilo Mastroiani (O máis estraño/ As chamadas perdidas, p. 304).

Preguntábanlle como fixera esa coviña, estilo Robert Mitchum (As voces baixas, p. 48).

Barbeado artístico. Mastroiani? Cantinflas? Marlon Brando? O intre das oportunidades. Despois non te queixes ( $O$ heroe, p. 34).

Fuera del rostro podemos buscar ejemplos de las manos:

Cando vexan un espectro, procuren fixarse nas súas mans. En concreto, nos seus cotobelos. Como o predicador falso d'A noite do cazador que interpretou Robert Mitchum, hainos que levan tatuada nunha man a palabra amor, e na outra, odio (A corpo aberto, p. 155).

Otro aspecto diferenciador de las personas son los gestos. Las coincidencias gestuales pueden ser azarosas, pero en la mayoría de los casos señalados por Rivas, nos encontramos delante de imitaciones deliberadas:

Romay mirou para o ceo agardando un sinal salvífico pero o único que divisou foi a Portomeñe ${ }^{19}$ balanceándose nunha lámpada estilo Errol Flynn (Galicia, Galicia, p. 52).

Abaneaba a súa efixie como un Frankenstein (O máis estraño / As chamadas perdidas, p. 392).

Sin duda el gesto más citado y recurrente en la obra de nuestro autor es la forma de caminar de Charlot:

\footnotetext{
${ }^{18}$ Por supuesto dentro de una realidad que es parte de la ficción narrativa, como en los filmes citados, en la realidad que es parte de la ficción cinematográfica.

${ }^{19}$ La cita procede de «Cirio no castelo», decimoquinto capítulo de No mellor país do mundo. Sucede que, a lo largo de esa crónica de ficción, al conselleiro Vázquez Portomeñe se le presenta como una persona pretenciosa que se afana en comportarse como los artistas del cine; recordemos que va a África disfrazado de Robert Redford en la película Memorias de África.
} 


\section{Tropelías. Revista de Teoría de la Literatura y Literatura Comparada, 30 (2018) \\ La caracterización de los personajes a través de las imágenes de cine en la obra de M. Rivas}

A memoria anda ao seu xeito vadío, vai a valmontes, cruza de xeito temerario a Avenida, camiña como o vagabundo de Charlot no cine Hércules (As voces baixas, p. 21).

Charles Chaplin convirtió el andar del vagabundo en la verdadera trama, en el guion de la película de la vida (Vicente Ferrer. Rumbo a las estrellas, con dificultades, p. 44).

Analicemos ahora las etopeyas, las descripciones de los rasgos psicológicos, morales o ideológicos de los personajes ${ }^{20}$. Entre el abundante grupo de citas referidas a estos aspectos nos encontramos con algunas que se refieren a un grupo humano, por ejemplo, a la humanidad, los gallegos o a la derecha política:

O ser humano é un energúmeno irracional, capaz de esmagar os seus conxéneres e derramar o planeta, incluso de forma xubilosa como aquel piloto con sombreiro cowboy e esporas, montado nun mísil nuclear e dando hurras, que retratou Stanley Kubrich na delirante Teléfono vermello? Voamos cara Moscova (sic) (A corpo aberto, p. 309).

As eleccións galegas son sempre como unha película de Hitchcock. Transcorren na metade dunha escada pero esa escada é a de incendios. Semella non pasar nada ata que xurde un Mcguffin, o elemento do suspense (Galicia, Galicia, p. 211).

Todo o mundo comeza a estar moi preocupado pola dereita española. Todos, menos a dereita española, que avanza decididamente cara ao futuro pretérito, en alegre excursión ao motel de Psicose (A corpo aberto, p. 147).

Otras citas se refieren a individuos concretos, mostrándonos aspectos de su personalidad como la hiperactividad, la vanidad o la cobardía, como podemos observar en los siguientes ejemplos:

Podemos reconstruír visualmente a súa secuencia triunfal. Mentres outros confiaban o destino á política audiovisual divina, el inauguraba teleclubes. A Lei de Prensa. Os calzóns atómicos de Palomares. O chapeo bombín de Londres...Mass Fraga construíu o seu personaxe coa técnica do nouveau cinema, mudando o guión da película ao ritmo da rodaxe (Galicia, Galicia, p. 274).

A biografía de Esperanza Aguirre titulábase "A presidenta", mais no programa empeñábase en falar de The Queen (A corpo aberto, p. 108).

Digamos que el non tiña madeira de heroe para interpretar Casabranca (Muller no baño, p. 70).

Permítasenos unas palabras sobre este último ejemplo, extraído de una de las páginas, a mi entender, más brillantes del autor de Monte Alto: el artículo titulado «Álvaro Cunqueiro e Ingrid Bergman». El escritor y la actriz no guardan ningún parecido, nunca coincidieron a lo largo de sus vidas. Su único rasgo común es haber muerto el mismo año. Sucede que Julio, un aragonés, plantó en su «Huerta de la Media Legua» un membrillo con el nombre del autor de Mondoñedo. En este jardín cultivaba también un rosal llamado Ingrid Bergman («Pois, nestoutro caso, un marmeleiro chamado Álvaro Cunqueiro salvou un pequeno paraíso e, con el, a Ingrid Bergman e os seus bicos, que arrecenden ás rosas de abril do ano Mil e Pico» (Muller no baño, p. 71), de modo que, como Dafne y Apolo o como los protagonistas de Duelo al sol (King Vidor, 1946), los personajes pudieron reverenciarse o fundirse formado parte de la flora. El jardín estaba amenazado por las obras de una

\footnotetext{
${ }^{20}$ Las alusiones a personajes y especialmente a políticos son abundantísimas. Aquí nos limitaremos a unos pocos ejemplos para que se pueda observar la técnica de Rivas, pero el espacio dedicado a dirigentes como Manuel Fraga, José María Aznar o Francisco Vázquez, se esté de acuerdo con ellos o no, darían para un amplio artículo.
} 
autopista y pudo salvarse gracias, entre otras acciones, a un reportaje del Heraldo de Aragón, titulado «¿Cuánto cuesta el membrillo Álvaro Cunqueiro?». De modo que Cunqueiro, que no tuvo madera de héroe de Casablanca - hermoso eufemismo para referirse a los episodios más controvertidos de la vida de este autor-, acaba por, metamorfoseado en árbol, salvar a la protagonista de la película citada y a sus besos de mil y pico primaveras, tantos besos como narraciones de Sherezade y tantas primaveras más como el autor deseaba a la lengua gallega.

En ocasiones Rivas describe la ideología, de su modo de pensar y actuar, de este modo denuncia la maldad, a violencia, la hipocresía...:

Nos seus mellores momentos, Pérez Varela ten algo de malo de película, pero dun malo gótico, de efectos especiais (Unha espía no reino de Galicia, p. 149).

Se un prefecto francés tivera actuado como se actuou en Pontedeume, poñendo un pobo patas arriba por mor dun corte de tráfico, e causando feridas a unha nena de dous anos, a tal autoridade estaría agora buscando emprego de extra nunha de Tarantino ou pescando fanecas en Córsega (Galicia, Galicia, p. 289).

O que si sorprende é que sexa precisamente o presidente da grande nación americana o que denuncie os efectos perniciosos da televisión sobre a infancia e a xuventude. É como escoitar ao Pato Donald criticar a factoría Walt Disney (Toxos e flores, p. 157).

Pero nuestro creador no se contenta con mostrarnos los personajes a partir de su parecido físico o psicológico con los entes cinematográficos, sino que va más allá y, en ocasiones, las criaturas de sus textos se definen, se asoman, a partir de las interpretaciones que ellos hacen de los habitantes del séptimo arte:

No avión, nos asentos de atrás, dúas rapazas comentaban $A$ vida secreta das palabras de Isabel Coixet. A súa forma de falar, ganduxando sensacións de medo e esperanza, resultaba curativa. Sen ver os seus rostros parecíame escoitar unha prolongación do filme (A corpo aberto, p. 152).

Quizás el ejemplo más elegante de este recurso lo encontramos en Todo é silencio. Mariscal, el cacique que ensalza a lo largo de toda la obra los personajes rudos y violentos interpretados por John Wayne:

Aínda que se hai unha boa moza, o trío é perfecto. Wayne, o cabalo e a namorada, por esa orde (Todo é silencio, p. 51).

Con Wayne e un cabalo. Con iso xa fas unha película (Todo é silencio, p. 51).

En un momento de la obra, el protagonista que decide presentarse a las elecciones municipales, pacta una entrevista con un periódico local. Durante la misma, le pregunta, ejerciendo de entrevistado entrevistador, a la periodista Lucía Santiso:

Que lle pareceu John Wayne?

A moza riu. Acabaría sendo ela a entrevistada.

-É doutros tempos. O home que matou a Liberty Valance. Aí si me gustou (Todo é silencio, p. 181).

La respuesta de la periodista desconcierta al capo que contesta con vehemencia: que «un home é un home [...] Iso non é doutro tempo, señorita. Iso é intemporal» (Todo é silencio, p. 181). El autor 
nos muestra de este modo el abismo en la concepción del mundo de ambos personajes a través de la interpretación de los papeles de este actor norteamericano. Para uno por ser la quintaesencia de lo masculino, del valor, de la fuerza como método para resolver los conflictos, representa el modelo a seguir, la figura que imitar; para la otra, pertenece al pasado y solo cuando actúa guiado por la generosidad y el desprendimiento aún a costa del sacrificio propio —en el filme Tom Doliphon (John Wayne) salva la vida a Ransom Stoddard (James Stewart) y como consecuencia este prospera y logra el amor de la mujer que ambos aman - es digno de aprecio. Sabemos, pues, cómo sienten, cómo ven el mundo los personajes no a partir de los parecidos sino de la forma en que interpretan a los héroes de las películas.

Quizás podamos decir, a modo de conclusión, que la fecunda idea de Julia Kristeva ${ }^{21}$, según la cual la escritura es una «lectura del corpus literario anterior» (Estébanez Calderón, 1999: 570) y el texto literario «absorción y réplica» (Estébanez Calderón, 1999: 570) de las obras previas, debería ser ampliada para reconocer el diálogo nutricional con otras artes, en especial la del cine y sus formas audiovisuales de narrar.

El cine contó, a lo largo del siglo XX, con más seguidores que ningún otro espectáculo. Su influencia llega a tal punto que, como pusieron de relieve Ricard Morant y Debra Westall, ha dejado su huella inclusoen la fraseología. La fama de las películas, de las bandas sonoras, de los personajes y de los intérpretes ha hecho posible que podamos definir a las personas e incluso a los objetos comparándolas con los del celuloide. Cuando los autores literarios, como es el caso de Manuel Rivas, se valen, de modo continuado, de este recurso, podemos deducir que el lector supuesto, «aquel que un escritor imagina que va a ser su lector previsible» (Estébanez, 1999: 602), es, necesariamente, un ser nacido cuando la tecnología del cine ya estaba muy desarrollada y formaba parte de la vida cotidiana; es decir, un homo filmicus.

Beaugrande y Dressler defienden que la intertextualidad debe ser definida como el conjunto de «factores que hacen depender la utilización adecuada de un texto del conocimiento que se tenga de otros textos anteriores» (1997: 45), frente a un uso más restrictivo de este término que implicaría «la presencia, en un determinado texto, de expresiones, temas y rasgos estructurales procedentes de otros textos» (Estébanez Calderón, 1999: 570). Si analizamos un fragmento como: «o bolso da Aguirre era en realidade unha arma. Só contiña un móbil, á maneira en que algúns personaxes do Oeste gardaba un revólver nunha Biblia encaracochada» (A corpo aberto, p. 108), observaremos que no se cita de un filme concreto; pero el lector supuesto, o al menos el ideal, debe ser capaz de desentrañar las referencias a filmes como El póquer de la muerte (Henry Hathaway, 1968) para entender plenamente el texto.

Recordemos que, como afirman Beaugrande y Dressler:

En ciertos tipos de textos como la parodia [...] el productor textual ha de consultar continuamente el texto principal para construir su discurso [...] y, con toda seguridad, los receptores textuales necesitarán conocer el texto previo para entender el actual (Beaugrande y Dressler, 1999: 45).

\footnotetext{
${ }^{21}$ Citada en Estébanez Calderón (1999: 570).
} 
Efectivamente Rivas emplea, en muchas ocasiones, las citas con intención paródica o humorística:

Por suposto que é de carne e óso, pero se puidésemos reconstruílo figuradamente, como quen novela un replicante de Blade Runner de Ridley Scott, Mass Fraga sería unha mestura soldado de chumbo de linotipia, telefonía, emisor de ondas, cátodos televisivos e un chimpín que abre pola pista forestal en Internet (Galicia, Galicia, p. 274).

Pero foi e saíu unha sintonía de Star Wars, despois unha gargallada tipo Jack Nicholson e unha lacónica mensaxe en inglés, seguida dun nítido «iManda carallo!» en galego (Muller no baño, p. 82).

Sin duda ejemplos como estos, empapados de ironía, son los más relevantes e interesantes desde el punto de vista estético. No obstante, nos interesa señalar aquí también los usos denotativos, sin cargas connotativas, como: «Gabriel prestoulle atención a un home que lle recordaba ao actor Monty Clift» (Os libros arden mal, p. 540), porque expresan la naturalidad con que el autor se dirige a su lector supuesto, necesariamente un cinéfilo ${ }^{22}$.

En nuestra opinión, lo más original del estilo de Rivas en lo que se refiere a la caracterización de los personajes a través del cine, lo encontramos en el uso de las interpretaciones de las películas para expresar la cosmovisión de sus personajes. Ya no se trata de la comparación con el aspecto de Mastroiani, con el supuesto carácter de Schwarzenegger, lo que define al protagonista sino la «lectura» que este realiza de un filme. Rivas nos sumerge así en un juego; en él, el diálogo entre el personaje y la película se convierte en el hilo de Ariadna mediante el que el lector puede interpretar de manera precisa el camino de salida del laberinto propuesto por el relato literario.

En definitiva, las referencias cinematográficas de Rivas constituyen un ejemplo de la fecundidad de la intertextualidad entre las artes y nos sirven para desentrañar el tipo de lector supuesto del autor gallego.

\section{Bibliografía primaria:}

RIVAS, Manuel (1985; 2010): Todo ben. Vigo, Xerais.

(1991): Os comedores de patacas. Vigo, Xerais, 10. ${ }^{\text {a }}$ ed., 2008.

(1992): Toxos e Flores. Vigo, Xerais.

(1993): En salvaxe compaña. Vigo, Xerais, 4. ${ }^{\text {e ed., }} 2008$.

- (1994): Galicia, el bonsái atlántico. Descripción del Antiguo Reino del Oeste. Madrid, El País-

Aguilar.

(1997): El periodismo es un cuento. Madrid, Alfaguara.

- (1998): O lapis do carpinteiro. Vigo, Xerais, 19. a ed., 2005.

- (1999): Galicia, Galicia. Vigo, Xerais

- (2000): A man dos paíños. Vigo, Xerais.

(2002): Muller no baño. Vigo, Xerais.

${ }^{22}$ Utilizamos aquí la palabra cinéfilo no como sinónima de experto en cine, sino con su valor etimológico de amante del cine. 
(2003): Do descoñecido ao descoñecido. Obra poética (1980-2003). A Coruña, Espiral Maior.

- (2004): Unha espía no reino de Galicia. Vigo, Xerais.

- (2005b): O heroe. Vigo, Xerais.

- (2006): Os libros arden mal. Vigo, Xerais.

(2008b): A corpo aberto. Vigo, Xerais.

- (2008d): Os Grouchos. Vigo, Xerais.

- (2009a): Episodios galegos. Tempos de esperpento. Vigo, Xerais.

- (2009b): A desaparición da neve. Madrid, Alfaguara.

- (2010b): Todo é silencio. Vigo, Xerais.

- (2011): O máis estraños. Contos reunidos. Vigo, Xerais.

(2012): As voces baixas. Vigo, Xerais.

\section{Filmografía de Manuel Rivas:}

\section{Autor adaptado}

CuerdA, José Luis (2003): La lengua de las mariposas. Sogepaq.

- (2007) «Primer amor», en VV. AA., Cortometrajes Fnac 1. Marefilms.

- (2013): Todo es silencio. Cameo.

Llovo, Ricardo (2001): Xinetes na tormenta. Pórtico de Comunicaciones S. L.

MartíneZ, Noemí - Esteban, Paula (1998): Que me queres, amor? Fondos do CGAI.

PALACIOS, Manuel (1999): La rosa de piedra. Fondos da TVG.

ReIXA, Antón (2002): El lápiz del carpintero. Morenafilms, Portozás visión y Sogecine.

\section{Guionista}

CUERDA, José Luis (2013): Todo es silencio. Cameo.

MCGREGOR, Emilio (2005): E punto en VV. AA., Haique botalos. A Fraga Maldita.

MARTín DE BLAS, Juan M. (1999): Galicia, arpa de niebla. Editrama.

\section{Director}

RIVAS, Manuel (2004): Mayday: llamada general, en VV. AA.: ¡Hay motivo!. Hay Motivo P. C.

\section{Colaborador}

SÈRAUDIE, Patrick (2007): Une histoire galicienne. Les films du paradoxe.

\section{Bibliografía secundaria}

AnTón, Patricia (2007): La novelística de Torrente Ballester y el cine: Los gozos y las sombras. Análisis comparativo-textual; en https://core.ac.uk/download/pdf/61897830.pdf (última consulta 15/01/2018). 
224 Tropelías. Revista de Teoría de la Literatura y Literatura Comparada, 30 (2018) Salvador Castro Otero

BEAUGRANDE, Robert-Alain de - DRESSLER. Wolfgang Ulrich (1997): Introducción a la lingüística del texto. Trad. Sebastián Bonilla. Barcelona. Ariel.

CAStro Otero, Salvador et al. (2011): Urbi et orbi. Dende o galego para o mundo. Pontevedra. Idea Gráfica.

EstÉBANEZ CALDERÓn, Demetrio (1999): Diccionario de términos literarios. Madrid. Alianza.

GARCÍA-ABAD GARCÍA, Teresa (2005): Intermedios. Estudios sobre literatura, teatro y cine. Madrid, Fundamentos.

GoYTisolo, Luis (1995): «El impacto de la imagen en la narrativa española contemporánea», Academia. Revista del Cine Español, 12, pp. 11-30.

Morant, Ricard - WeSTALl, Debra (2005): «Lo que el cine nos dejó: la herencia fraseológica», en J. de D. LuQue DurÁn y A. PAMIEs Bertrán, eds., La creatividad en el lenguaje: colocaciones idiomáticas y fraseológicas. Granada, Granada lingvistica. 